\title{
A descriptive study of lateral spondylolisthesis in patients with adult scoliosis
}

\author{
P Knott ${ }^{*}$, S Thompson ${ }^{2}$, S Mardjetko ${ }^{2}$ \\ From 8th International Conference on Conservative Management of Spinal Deformities and SOSORT 2011 \\ Annual Meeting \\ Barcelona, Spain. 19-21 May 2011
}

Lateral Spondylolisthesis is seen as a consequence of degenerative disc disease. It occurs primarily in the lumbar spine, and is often associated with adult degenerative scoliosis. When it occurs, it can result in severe back pain from disc instability and radicular leg pain from nerve root compression [1-6].

This is a descriptive study of a series of 32 patients with Lateral Lumbar Spondylolisthesis to evaluate the demographics of the population that this occurs in, the symptoms that it causes, and the association that it has with scoliosis.

All patients seen by the authors in a spinal deformity clinic during the calendar year 2010 had their radiographs screened for evidence of lateral Spondylolisthesis. If the 1319 patients screened, this condition was found in 32 patients. They were included if their Spondylolisthesis was greater than $2 \mathrm{~mm}$. The cervical, thoracic and lumbar films were screened, but all 32 patients had their lateral spondylolisthesis in the lumbar spine only.

They were primarily female (84\%) and averaged 63 years of age. The youngest patient seen was 35 years old and had a congenital Klippel-Feil Syndrome and congenital scoliosis in the lumbar spine. The others had primarily adult degenerative scoliosis. There was a high prevalence of osteoporosis (41\%).

Patients primarily complained of low back pain (94\%), but $22 \%$ also complained of radicular leg pain. Two patients who did not complain of either leg or back pain both had Down Syndrome. Radiographs showed degenerative scoliosis in all patients, with an average lumbar curve of 50 degrees.

\section{Author details}

'Rosalind Franklin University of Medicine and Science, North Chicago, USA.

${ }^{2}$ lllinois Bone and Joint Institute, USA.

Published: 27 January 2012

\section{References}

1. Libson E, Bloom RA, et al: Scoliosis in young men with spondylolysis or spondylolisthesis. A comparative study in symptomatic and asymptomatic subjects. Spine 1984, 9(5):445-447.

2. McPhee IB, O'Brien JP: Scoliosis in symptomatic spondylolisthesis. J Bone Joint Surg Br 1980, 62-B(2):155-157.

3. Ploumis A, Transfeldt EE: Anatomic changes in lateral spondylolisthesis associated with adult lumbar scoliosis. Spine 2005, 30:E671-5.

4. Pneumaticos SG, Esses SI: Scoliosis associated with lumbar spondylolisthesis: a case presentation and review of the literature. Spine J 2003, 3(4):321-324

5. Reddy SJ, Al-Holou WN, et al: Traumatic lateral spondylolisthesis of the lumbar spine with a unilateral locked facet: description of an unusual injury, probable mechanism, and management. J Neurosurg Spine 2008, 9(6):576-580.

6. Toyone T, Tanaka T, et al: Anatomic changes in lateral spondylolisthesis associated with adult lumbar scoliosis. Spine 2005, 30(22):E671-67.

doi:10.1186/1748-7161-7-S1-P13

Cite this article as: Knott et al.: A descriptive study of lateral spondylolisthesis in patients with adult scoliosis. Scoliosis 2012 7(Suppl 1):P13.

Submit your next manuscript to BioMed Central and take full advantage of:

- Convenient online submission

- Thorough peer review

- No space constraints or color figure charges

- Immediate publication on acceptance

- Inclusion in PubMed, CAS, Scopus and Google Scholar

- Research which is freely available for redistribution 